\title{
Ethical internationalisation in higher education: Interfaces with international development and sustainability
}

\author{
Karen Pashby
}

Department of Educational Policy Studies, University of Alberta, Edmonton, Canada

\author{
Vanessa Andreotti \\ Department of Educational Studies, University of British Columbia, Vancouver, \\ Canada
}

Correspondence: University of Alberta, Department of Educational Policy Studies, 5104, Education North, Edmonton, AB T6G 2G5, pashby@ualberta.ca

Karen Pashby is a postdoctoral fellow at the Centre for Global Citizenship Education and Research at the University of Alberta. Previously she held a postdoctoral research position at the University of Oulu. She earned her PhD at the Ontario Institute for Studies in Education where she co-ordinated and instructed the Global Citizenship and Sustainable Development cohort in the initial teacher education program (secondary panel).

Vanessa Andreotti is Associate Professor at the University of British Columbia and holds a Canada Research Chair in Race, Inequalities and Global Change. She is also a research fellow at the University of Oulu, where she was Chair of Global Education from 2010 to 2013, and at the Centre for Global Citizenship Education at the University of Alberta

Acknowledgements: This research has been conducted as part of The Ethical Internationalisation in Higher Education project (2013-2015). We would like to acknowledge the Academy of Finland for funding this project and the University of Oulu for housing it. The authors would like to acknowledge Sharon Stein for invaluable feedback and support with revisions and editing, Nadja Widel for her help with an earlier version of this paper, and Johan Öhman and Louise Sund for their input. We would also like to thank Johan Öhman for organizing the special issue and the co-contributors for the excellent discussion. We are indebted to the blind reviewers for their thoughtful constructive feedback. Finally, we would like to dedicate this paper in memory of our cherished colleague Michelle Nicolson. 


\title{
Ethical internationalisation in higher education: Interfaces with international development and sustainability
}

\author{
This analysis is situated within a larger project focusing on ethics and \\ internationalisation in higher education. Internationalisation is occurring at a fast \\ pace and encompasses overlapping and contradictory aims largely framed by \\ market imperatives. At the same time, institutions of higher education \\ increasingly promote sustainability. We use a framework informed by decolonial \\ theories to map different orientations of internationalism at the interface of \\ sustainability and international development in the context of neoliberalism. To \\ examine these interfaces we offer a social cartography that locates intersections \\ of neoliberal, liberal, and critical discourses within an internally contested but \\ enduring modern/colonial imaginary. We demonstrate the generative potential of \\ the social cartography by drawing on examples from strategy documents relating \\ to internationalisation from universities in Canada, Finland, Ireland, New \\ Zealand, Sweden and the U. K.
}

Keywords: higher education; education for sustainability; development education; internationalisation in education; postcolonial theory in education

On November 9, 2014, the International Conference on Higher Education (HE) for Sustainable in Development occurred in Nagoya, Japan ${ }^{\mathrm{i}}$. It was a held the day before the UNESCO World Conference that marked the end of the UN Decade for Education for Sustainable Development (ESD). Participants representing government and university groups as well as UN organizations produced a Declaration on Higher Education for Sustainable Development which was to inform discussions at the UNESCO World Conference. In the declaration they promoted a 'transformative role of higher education towards sustainable development' through 'transformative learning and research' (HESD, 2014). Earlier initiatives include the Talloires Declaration (ULSF, 1990) to which more than 400 institutions of Higher Education ${ }^{\mathrm{ii}}$ (HEIs) signed a commitment to integrate ESD into their teaching and operations, and the Copernicus Charter, signed by 
320 European HEIs in 38 countries by 2006 (Copernicus Campus, 2006/2007) among others. These examples reflect a significant degree of international consensus regarding the importance of institutes of higher education (HEIs) playing a leading and even transformative role in promoting sustainable development world-wide. At the same time, HEIs are being directed into intensifying processes of internationalisation. In this paper, we link the trends of sustainable development and internationalisation in higher education and use social cartography (Paulston, 1999, 2000) as a means to explore theoretical conundrums and contradictory ethical implications of these overlapping policy agendas. Specifically, we use the cartography to make visible the distinct and overlapping discursive orientations evident in internationalisation documents recently published by universities in Canada, Finland, Ireland, New Zealand, Sweden, and the UK.

We begin the paper by examining the intersecting fields of ESD and internationalisation of HE. Next we build a conceptual framework drawing from decolonial critiques of modernity and development. We then present a social cartography that considers the distinctions and intersections of dominant discursive configurations of policy and practices of higher education in the context of internationalisation. Using this cartography, we examine the higher education policies in six countries in order to illustrate how the discourses international development and sustainability can, as Bonnet (2013) asserts, 'function as a banner for people of very different motivations and vested interests' (259), and particularly so in the context of internationalisation in HE. We conclude by reiterating the need to deepen our analyses of ethics at the intersections of sustainable development and internationalisation in HE. 


\section{(Higher) Education for sustainable development}

Glover, Peters, and Haslett (2011) argue there is no strong evidence of a deep embrace of ESD at the core functioning of universities (see also Calder and Dautremont-Smith, 2009). According to Bessant, Robinson and Ormerod (2015), HE has a 'fundamental responsibility towards sustainability', and yet despite many developments promoting ESD in HE, 'genuinely transformative ESD requires more radical and fundamental change' (418). To be transformative such changes will have to address the systemic ways that methods of resource use and extraction reinforce environmental exploitation. This will also require identifying and dismantling social, cultural and epistemic hierarchies that have become taken for granted. A lack of coherence around what ESD looks like in HE policy and in pedagogy reflects the challenges of defining and mainstreaming ESD within the operations and rationales of HEIs in the current global context.

Drawing on Orr (1992), Thomas (2004) determines that understanding sustainable development is an increasingly unavoidable imperative for contemporary HE graduates. He asserts that students must require a 'literacy' of sustainability that includes: accepting the 'probability of survival of our species'; developing an attitude of care or stewardship; gaining knowledge needed to comprehend the interrelatedness of 'intellect, hands, heart'; and acquiring the practical competence to act on basis of knowledge and feeling (Thomas, 2004, 35).Yet, making ESD central to the work of HEIs remains a contested ideal tied up in wider debates, and there is a lack of clarity around several key factors: the roots of the global problems, the role of education within responses to these problems, and the challenges of conceptualizing and operationalizing environmental education broadly and ESD more specifically (see, e.g. Jickling and Wals, 2012; and Van Poeck, Goeminne, and Vandenabelle [this issue]). 
Orr (1994) anticipated a central paradox of ESD related to the aims of education:

Education is not widely regarded as a problem, although a lack of it is. The conventional wisdom holds that all education is good, and the more one has of it, the better... The truth is that without significant precautions, education can equip people merely to be more effective vandals of the earth. (5)

Two decades later, Orr's (1994) caution rings particularly true. Reflecting on a wide range of environmental education activities with a particular focus on New Zealand, Hayward (2013) recognizes that ESD is implicated in the current neoliberal era of education, similarly to Kopnina and Cherniak (this issue) and Van Poeck, Goeminne and Vandenabelle (this issue), and as thoroughly explored in the recent special issue of this journal on the topic. In that special issue, Huckle and Wals (2015) argued that literature written in support of the UN decade for ESD did not recognize neoliberalism as a hegemonic force nor did it challenge its effects in stopping the changes that could support genuine sustainability (491). In the introduction to that special issue, Hursh, Henderson and Greenwood (2015) define a key characteristic of neoliberalism as a transformation of the role of the state from that of supporter of social democracy for the public good that of enabler to competitive markets who provide for the public good (303). Correspondingly, the role of the individual in relation to the state becomes to 'best operate within markets and within these occupy what is akin to the subject position of entrepreneurs, fulfilling their own needs and pursuing their own goals in competition with others' (Hursh, Henderson, and Greenwood, 303-304). In practice, they find that a neoliberal climate for education serves to narrow and restrict curriculum, and environmental education is marginalized (307). At the same time, in this context, a concern is raised around the civic role of the individual as neoliberal subject. In a narrowed curriculum, individual behaviours can stand in for and thus avoid 
the analysis and transformation of various social factors and systemic power relations that are at the heart of environmental issues. Hayward (2013) finds that where it is practiced, there is a tendency in ESD towards over-emphasizing individual behavioural change. Similarly, Mochizuiki and Bryan (2015), who focus on how climate change is taken up in environmental education, find that it is done so 'often in a superficial manner which overemphasizes individual level responses such as recycling, reusing and reducing at the expense of consideration of ...wider social processes' (22) (see also Huckle and Wals, 2015).

In sum, ESD remains a contested and ambivalent term in higher education, and in education more broadly. When considering ESD in the context of neoliberalism, a particular concern is the tendency for civic engagement to be reduced to individual behaviour.

\section{Internationalisation in higher education}

In parallel to a complex and contested focus on ESD in HE, there is currently a major strategic focus — both at national levels and within individual universities — on internationalisation. This includes a variety of trends and processes that involve movements of students and staff in and out of HEIs; partnership building for collaboration, prestige and capacity building; and various approaches to internationalising curriculum including joint programs, international content, built-in experiences abroad, overseas campuses and the exporting of credentialing. While internationalisation is a strategic priority of HEIs in terms of reputation building and rankings, the broad and vague conceptualizations of internationalising HE also incorporate calls for including more global perspectives, promoting global citizenship, and working for international and sustainable development (Bourn, 2011; Buchan, 
Spellerberg and Blum, 2007).

Recent scholarship regarding internationalisation in HE raises related concerns to those raised about ESD. Curriculum internationalisation tends to reinforce deficit views of diversity and fails to challenge ethnocentrism (Kelly, 2000; Tarc, 2009). Such policies leverage and exploit the transnational identity capital of international student and staff (Kim, 2010). Also, study abroad and volunteering schemes (Zemach-Bersin, 2007), international development partnerships (Kapoor, 2008; McEwan, 2009), and strategies for global citizenship (Andreotti et al., 2010; Andreotti and Souza, 2011) can reinforce global and local power imbalances. This literature asserts HE policies, partnerships, and curriculum design are largely framed by neoliberal market imperatives that only value epistemic diversity to the extent that it can be domesticated and corporatized (Kelly, 2000).

In these ways, internationalisation practices can reproduce ideals of exceptionalism, entitlement, and (market) expansionism as they de-emphasize issues of global ethics (Khoo, 2012). Thus, despite calls in the HE and ESD literature for a more complex and transformative approach to the content and nature of educating for internationalisation and sustainable development (e.g., Bourn, 2011), currently the dominance of neoliberal views of the role of universities based on economic rationales reduces and even forecloses opportunities to critically examine the sets of assumptions underlying just what/who institutions of higher education (HEIs) are helping to sustain and why/how/where they need to be sustained (Andreotti et. al., 2010; Kelly, 2000; Kim, 2010; McEwan, 2009). 


\section{Conceptual framework: ESD and internationalisation within a modern-colonial global imaginary}

In order to consider how internationalisation, international development, and sustainability intersect in rationales for higher education, in this article we have chosen to draw on the decolonial critiques offered by Walter Mignolo (2000a, 2000b, 2002, 2011) and Denise Ferreira da Silva $(2007,2009,2013)$ (see also Andreotti et al., 2015). Their critiques focus on what we summarize as a contested, but enduring modern/colonial global imaginary (Mignolo, 2011; Silva, 2007; Stein and Andreotti, 2015; Stein and Andreotti, forthcoming). This imaginary mediates our relationship with the world, animating specific desires, and mobilizing specific subjectivities. Most importantly, it restricts intelligibility: what lies outside of it is not what we do not imagine, but what we cannot imagine from within it. Thus, even when we critique aspects of the imaginary that we find problematic, our proposals for alternatives (in order to be intelligible) tend to, paradoxically, remain within it.

The dominant global imaginary (represented in the singular form) represents the longue durée of dynamic and plural configurations of modernity and post-modernity. These configurations are circumscribed by an onto-epistemic matrix of anthropocentric, Cartesian, evolutionary, dialectical, teleological, utilitarian, allochronic, and universal reasoning sustained by desires for seamless engineered progress, heroic human agency, and totalizing forms of knowledge production grounded on linear causality (Andreotti, 2014). Different combinations of elements in this matrix produce different vocabularies/ideologies in different contexts (e.g. capitalism and socialism), but they remain within the same grammar of ontological and epistemological possibilities. Hence historicizing and mapping the dynamics of the modern/colonial grammar that demarcates this imaginary is an important task in attempting to reach its edges (by 
interrupting our satisfaction with it) and opening the possibility for imagining otherwise. Without reaching the edges of this imaginary — and identifying our hidden attachments and investments within it—our critical attempts to think or to be differently (within it) can easily become a circular self-affirming (and often self-serving) exercise.

In relation to the newest iteration of the matrix, in particular neoliberalism, both Mignolo and Ferreira da Silva (and others within their respective fields) emphasize the intimate historical relationship between the modern nation state and global capitalism. They draw attention to a façade of modernity that has projected the modern nation state as a benevolent entity created to deliver on the promise of engineered progress, cohesion, affluence and security, in order to mask its central objective: to protect the interest of property. Hidden by this façade is the historical and on-going processes of racialization, appropriation, dispossession, destitution, exploitation and genocide that are constitutive of the project of modernity and necessary for its realization. Furthermore, when the interests of capital no longer converge with the interests of citizens (e.g. in the context of post-state financial capitalism), the façade collapses (see Andreotti et. al., 2015; Mooers, 2014). This analysis has several implications for the context of ESD. As Kopnina and Cherniak (this issue) points out, not only does the extension of resources to those identified as disadvantaged through so-called development spread unsustainable economic practices, there are also vastly detrimental impacts on non-human species and ecosystems. When circumscribed by the neoliberal orientation within the dominant modern/colonial global imaginary, 'ESD becomes enmeshed in the economism, scientism, consumerism, pre-specification, managerialism, standardisation of language and procedures through mechanically applied proformas that are all instruments of a drive to control, exploit and possess' (Bonnet 2013, 259). 
In summary, decolonial critiques bring attention to three key problematic aspects of this modern-colonial imaginary relevant to critical engagement with ethical and political issues related to ESD in HE. These three aspects are of particular concern in the context of internationalisation as a strategic priority: a) The assumption of modern teleology embedded in notions of progress in linear time, which is imagined as the benevolent global expansion of capitalism; b) An anthropocentric Cartesian conceptualization of agency based on the supremacy of rationality and the autonomy of the individual; and c) An approach to problem solving based on applying more of the same type of knowledge (e.g. more capitalism prescribed as a cure for the problems that capitalism has created).

This last point is also reflected in the push for research to be evidence-based, founded on the assumption that social interventions can be engineered in ways that guarantee prescribed outcomes (see Andreotti, 2013, c). This complements Bonnet's (2013) critique of ESD's basis in western scientific rationality and the 'metaphysics of mastery'. Bonnet argues that in modern and late-modern times rationality has been applied to specific goals to 'categorise and exploit', and 'increasingly these purposes have revolved around control and exploitation of the natural world....[through] the operation in the West of a deep set of motives that install in us a particular version of reality' (259).

Based on the theoretical grounding outlined above, the wider project that is the platform for this paper-Ethical Internationalisation in Higher Education in Times of Global Crisesiii_takes up Roy's (2006) call for a strategic and insurgent critical praxis that works through complexities and double binds with the aim of moving current discussions. Roy (2006) speaks of an ethics of a double-voiced articulation that 'put[s] to use hegemonic discourses, while imbuing them with a signal difference, deferential 
yet disruptive' (23). She states that: 'the ethics of doubleness is a provisional and improvisional praxis, one [...] which cannot claim professional innocence' (23). Inspired by this doubleness and by decolonial critique, our analyses in this paper and the efforts of the project more generally are oriented by the need to both: a) make visible complicated relations of complicity within mainstream ideas of sustainability, its place alongside notions of international development, progress, and sustainability, and the role of HEIs in knowledge (re)production; and b) create new vocabularies, analyses, and possibilities for intervention while acknowledging the ongoing implication of the university and of academics in 'the wheel of global capitalism, as much constructed by as constructor of the process' (Harvey, 2000, 237 as cited by Roy, 2006, 20).

\section{A heuristic to map challenges, complexities, and possibilities for ethical internationalism}

The larger Ethical Internationalism in Higher Education project on which we draw in this paper aims to create social cartographies (Paulston, 1999, 2000) of shifting imaginaries of HE and of trends in internationalisation. Social cartographies are performative visual devices that aim to clarify tensions within and between intellectual communities or discursive orientations. They are social cartographies in that they provide a 'visual dialogue as a way of communicating how we see the social changes developing in the world around us' (Paulston \& Liebman, 1994, 215) ${ }^{\mathrm{i}}$. We understand its purpose as a methodology as aiding us in problematizing common sense imaginaries and drawing 'attention to the intersections of normative claims in ways that amplify the ambivalences, contradictions and limits of common discursive assemblages' (Andreotti et al., 2016, 1). Cartographies are used to visualize a relevant problem from different perspectives and to trace each way of framing the problem and its proposed solutions to their implicit theoretical and metaphysical roots (Rust and Kenderes, 2011). They show 
how concrete problems and solutions are inescapably embedded in theoretical and metaphysical abstractions that are often left unexamined (Weidman and Jacob, 2011), and allow for various perspectives and interpretations to be contemplated without imposing a demand for immediate consensus (Paulston, 1999). Although cartographies can be read as representational or normative devices if used as interpretative tools (which some of our project partners have done), our use of social cartographies in this article is tentative, situated and akin to other post-structuralist uses that aim to 'trouble tidy binaries' and to 'deliberately hold together necessary incompatibilities' (Lather, 2006, 36).

Specifically, our intention is to generate deeper analyses, to illuminate complicities (including our own) and paradoxes and to facilitate more self-reflexive and consciously situated decisions in each context where it is used (see also Paulston, 2000). In this way, cartographies enable us to put into practice our working definition of ethical internationalisation, premised on a commitment to: intelligibility, making inequities and inequalities visible and articulating some of the taken-for-granted assumptions and paradoxes at their core; dissent, engaging in the complex task of resisting the rules, principles and precepts that reassert inequities, while acknowledging our complicities; and solidarity, coming together across and with difference (Andreotti, Pashby, and Nicolson, 2014).

In this article, we draw selectively on a larger policy analysis (Pashby and Andreotti, 2014) to illustrate the intersections of higher education discourses that articulate discursive areas of conflation and contradiction. ${ }^{\mathrm{v}}$ Our social cartography (Andreotti et al., 2016) consists of three major discursive configurations identified in the literature of higher education: neoliberal, liberal and critical (see Figure 1). The choice of these 
distinctions is informed by the theoretical framework of the project consisting of critiques of neoliberalism, critiques of liberalism and the liberal subject, and critiques of modernity. We have also mapped four areas of interface. These are not discrete and are both internally contested and externally over-lapping, but they do provide a way to think through and interrogate well intended interventions (Andreotti et al., 2014). In this section we outline the three discursive configurations and four interfaces. We will later provide examples from the university documents to help us identify both foreclosures and possible openings of foreclosures as we attempt to articulate some of the silences in conceptualizations and interventions related both to international development (Baaz, 2005; Kaapor, 2008; McEwan, 2009) and to sustainability (e.g. Banerjee, 2003) in the context of the rush to internationalise HEIs.

We use the word discourse in a Foucaultian (1971) sense in that discursive configurations are vocabularies, or ways of speaking, generated within the ontoepistemic grammatical matrix of the dominant modern-colonial global imaginary described in the previous section. We consider internationalisation, international development, and sustainability as intersecting discursive fields. A discursive field consists of particular genres that are related contextually through constructions of diagnoses, prognoses, and calls for action (Camicia and Franklin, 313, drawing on Steinberg, 1999). In this sense, within these related fields discourses articulate and therefore make the social condition conceivable and comprehensible as they reflect distinct orientations. We use the term discursive configuration to refer to different groups of discourses mobilized within and across fields. Dominant discourses are 'those that in the social relations of power at a given moment come to assume authority and confer status - reflect the material relations that render them dominant' (Goldberg, 1993, 194). The literature has described neoliberalism as a dominant discourse, 
however, there are other sets of discourses operating to either mediate or be mediated by the dominant discourse. The social cartography thus includes the interfaces between discursive configurations to capture these interactions. By foregrounding the moderncolonial imaginary in our theoretical framework, we locate the cartography in a wider modern imaginary in which the three discursive configurations and their interfaces are embedded.

The first of three discursive configurations identified in the social cartography is neoliberal. Similar to the critiques of neoliberalism in ESD (e.g., Hursh, Henderson, and Greenwood, 2015), it is made particularly evident in the context of public sector austerity and state defunding of higher education. This discursive orientation animates a corporate imaginary of the university (Barnett, 2013) and plays out through practices of academic capitalism including income generation and branding (Slaughter and Rhoades, 2004). In the neoliberal discursive orientation, the university is accountable to the market, and students are clients who enter into transactions with the university and with instructors so that knowledge is significant in terms of its exchange value. The main core business of the university is centered on the provision of credentials, the lending of expertise, and the production of commercial innovations. Thus knowledge, research, teaching and service are commodified. The buzz words of international development and sustainability can accordingly become part of branding and marketing as well as providing avenues for commercial ideas and revenue generation. Yet, as Hursh, Henderson and Greenwood (2015) point out, there is not one neoliberalism but 'neoliberalisms' that differ across contexts, settings, and countries (300). In this study we consider cross-cutting themes and present a snap shot of internationalisation strategies while acknowledging that neoliberalism is always being 'made and remade, and new effects are being felt across contexts, settings, and countries' (300). In the 
context of the intensification of internationalisation in HE, we consider both how discourses of international development and sustainability are indicative of this flux and also how this flux is implicated in the onto-epistemic grammar of modernity evident across contexts. We also consider the extent to which (at least) two other discursive orientations are evident and are intersecting with neoliberalism.

In the second discursive orientation in the social cartography, a liberal discursive configuration the university is accountable to the state and not, as in the neoliberal configuration, primarily to the market. Based in a civic imaginary, the university provides a public good in that education is inherently valuable to forming national citizens who will contribute to the future progress and development of society. It is tied to a Keynesian orientation to economics wherein the state plays a key role in welfare and redistribution (Andreotti et al., 2016). Research is valued as the source of answers for society's problems, and education is an apparatus of representational democracy and participation in established institutions. This civic imaginary is extended to widening access to international students, promoting capacity building initiatives in so-called developing countries, and solving environmental problems. However, applying a critical modernity framework, there is a potential foreclosure overlooked in the liberal discursive orientation's focus on educating the future citizenry: the problems the university is benevolently solving and the access to knowledge it is granting are complicit in material and epistemic violence. Sustainment of the civic space of higher education depends on the construction and sustainability of a so-called First/developed world that in turn depends on an unequal distribution of wealth and power producing a so-called Third/developing world. The latter is perceived as lacking the skills and knowledge of education (Spivak 1999, 2002; Roy, 2005). The material dimensions of reality and a perceived lack of development are implicitly tied to an epistemic 
dimension so that in a liberal humanist perspective, knowledges not intelligible to modernity are perceived as ignorance and more of the knowledge embedded in modernity is used for solutions to this perceived lack (see also Sousa Santos, 2007).

Third, a critical discursive configuration seeks to interrogate inequitable systems of power and knowledge and unequal patterns of the distribution of resources and symbolic value. This requires targeting oppressive patterns (including capitalist exploitation and processes of racialization) in which normalized and even benevolent forms of thinking and acting are implicated. Like the liberal discursive configuration, the critical orientation evokes a civic imaginary where the university can serve a public good through including a plurality of voices; yet, it focuses on promoting radical forms of democracy. It is also distinct in its aims. Whereas the liberal configuration centres on and tends to reproduce a singular and homogenous narrative of the nation state and of development, the critical configuration critiques patterns of systemic inequities, acknowledges systems of oppression, and includes as a key discourse the need to transform and pluralise the possibilities for civic society. It does not take the university for granted, recognizing the extent to which it is an elitist space and attempting to make it accountable based on its contribution to the public good and particularly to marginalized communities. In this discursive orientation, sustainability and environmental concerns cannot be seen as isolated problems but as tied to wider systems of social, cultural, economic, and political inequalities. Furthermore, a critical orientation problematizes the roles of helper and helpee in a context of international and sustainable development asserting the importance of local perspectives and the benefits of diverse voices and engagements with difference. A critical orientation promotes participatory and alternative development frameworks in approaches to sustainable development. 
We recognize that these three discursive configurations and their orientations are internally and externally contested and interconnected: they do not exist in isolation from one another, and they operate within a wider modern grammar. The second part of the social cartography helps to map four interfaces between these different configurations: neoliberal-liberal, liberal-critical, critical-neoliberal, and all three configurations at once (see Figure 1). This helps to make intelligible the spaces of ambivalence whereby a signifier — such as international development or sustainabilitycan be applied so as to evoke multiple meanings. The interfaces represent spaces where two or more discursive orientations overlap and/or where one orientation strongly frames, influences, and/or mediates another orientation.

Figure 1: Ethical Internationalisation in Higher Education Project social cartography (based on an applied version of the figure included in Andreotti et al. [2016], 10)

We find some key themes at each interface. For example, an economic rationalization of what were formerly civic processes and meanings often defines the neoliberal-liberal interface. At the liberal-critical interface a deeper recognition of injustices and the responsibility of the institution to address them are more evident than in the liberal discursive orientation; however, given that the liberal configuration tends to be more prevalent than the critical, at the liberal-critical interface the focus is on personal rather than systemic change. Perhaps the most interesting is the critical-neoliberal interface which we identify in cases where critical strategies are used to defend interests framed in economic terms. For example, the economy can be framed as a common good and defending the entitlements of clients and stakeholders can evoke commitments to fairness and justice. The fourth interface is where signifiers that appeal to all three discursive orientations are deployed. 


\section{Mapping 'international development' and 'sustainability': applying the heuristic}

We used the cartography to map and consider the ways sustainability and international development are signifiers at the intersections of various overlapping and potentially contradictory articulations in documents describing internationalisation in HE. Specifically, we drew on university documents that are broad university strategies or reports as well as specific documents relating to internationalisation. The documents come from twelve HEIs in Canada, Finland, Ireland, New Zealand, Sweden, and the U. $\mathrm{K}$. We selected national contexts where universities host large numbers of international students and aim to intensify partnerships and educational activity abroad. ${ }^{\mathrm{vi}}$ These were also HEIs from where we had project partners participating in collecting data for the wider project (including surveys with students and faculty members and interviews with administrators and staff working directly on internationalisation policies and programs). We purposefully selected quotations from the documents with content related to internationalisation, international development, and sustainability. We then analyzed some key themes evident in these examples that corresponded with the three discursive configurations and four interfaces. We considered where the quotations from the text fit on our social cartography. It is important to note that methodologically, the purpose of the use of examples was not to make conclusive judgements as to whether or not the documents or university policy reflect ethical or unethical policies; rather, we use them here as illustrative of wider conflations and paradoxes embedded in the complex and confusing understandings of sustainability and international development in HEIs. In this sense, we were fitting the examples with the social cartography to provide a nuance into our understanding of the key aspects of the heuristic which serves as a reflexive tool and to begin to try to make visible some of the contradictions and overlaps. While the larger data set will reveal contextual differences and nuances specific to each 
university, in this paper we consider specifically how this set of documents relates to the social cartography and what types of insights can be evoked through such a mapping. The methodology is limited to that purpose. The purpose of our analysis is to provoke conversations and discussions, as we intend for this mapping and its focus on the way dominant discourses interface to provide some reflexive prompts for those of us both studying internationalisation and working within increasingly internationalised contexts in our day to day work.

\section{Mapping 'International development'}

In this analysis we found that across the documents studied, in policies and practices relating to internationalising $\mathrm{HE}$, international development is a signifier that is deployed with multiple meanings and is understood differently depending on different discursive configurations. Interpreted from a neoliberal discursive configuration, we found international development to be mainly about expanding global capitalism where it is assumed that dispensing allegedly universal knowledge/education in the service of capitalism can advance international development. It is also assumed that international development represents an opportunity for business that is mutually beneficial, and that partnerships enable progress.

The international arena itself is understood largely in relation on to global economy which defines tiers of desirable countries for partnerships and for recruiting students. For example, in its international resource document, the University of Alberta (Canada) identifies three 'tiers' of strategic international partnerships: Tier I: USA, Mexico, China, India, Germany, Brazil (comprehensive focus on all areas of the international agenda and priority for senior administrators and flagship activities); Tier II: Korea, Japan, Singapore, France (focus on research and recruitment, limited role for senior 
administrators); Tier III: Vietnam, Malaysia, Gulf States, Egypt Turkey, Iran, Chile, East Africa, Nigeria (priority on recruitment) (UA, 2010, 6).

When mapping selected examples from the documents to the liberal discursive configuration, we found international development to be largely articulated as the imperative to 'help' (Heron, 2007) those who are perceived as lacking development through dispensing expertise through knowledge, education, values, governance systems, planning, medical care, etc. Further, anything international is presented as collaborative, positive and as leading to problem solving and resolving conflict. For example, though the University of Alberta (2010) sets up the three-tiered strategic regional partnership priorities, it also recognizes the importance of 'working with underprivileged communities and with low income countries and regions in the world... [by] engag[ing] initiatives and projects aimed at enhancing the quality of life for these communities' (6). It also aims to 'transform the University into a microcosm of global citizenship with a strong commitment to seeking mutual understanding and respect between cultures, fostering curiosity and open mindedness in learning about people from all around the world' (2).

The neoliberal-liberal interface is thus expressed in a reassertion of global power hierarchies (literally through a tiered approach) and through market-driven impulses (focusing on ranking and recruitment) which are not understood to be in tension with a neutral, positive idea of global citizenship and learning about the world. The University of Helsinki's strategic plan, for example, expresses a strategic understanding of current geopolitical positions as related to its own area of expertise:

East Asian countries have asserted their position in international politics. Major global challenges such as climate change, health promotion, sustainable use of 
natural resources and conflict prevention will create opportunities to strengthen the role of a multidisciplinary university in these developments. (UH, 2012, 8)

In another example of this interface, Simon Fraser University's (SFU) (Canada) International Engagement Strategy (2013) prioritizes development partnerships that align with government policy linking international development and international education with trade priorities (see Government of Canada, 2014, 9). This strategic approach 'affords SFU early access to emerging regions for international collaborations and recruitment' (10). These examples are consistent with the literature speaking to a dominance of neoliberal orientations, and in these examples, we see how it interfaces with a liberal orientation.

A critical discursive orientation interrogates and interjects into a singular story of development. Questioning to what extent the 'help' in the liberal orientation dispenses public goods of universal worth, a critical orientation aims towards alternative, participatory, or post-development initiatives. It places more focus on honouring and responding to local contexts and local voices. Although there are not many examples in the documents of the critical discursive configuration, there are hints at it in interfaces with the liberal configuration. For example, UBC's internationalisation strategy (2011), which, like University of Alberta's, prioritizes international partnerships by strategic regions, also emphasizes the need to 'respond to different starting points and different local conditions in each region' (15). The National University of Ireland at Galway articulates a strong liberal rationale for 'a university meeting its responsibilities to pursue ethical internationalisation activities, and to make lasting contributions to the betterment of people's lives across the world' (NUIG, 2014, 1). And significantly, this liberal oriented rationale interfaces with a critical one: as a 'historic university in one of the world's economically privileged nations', NUIG 'endeavors to promote sustainable 
international development, human rights, and globally conscientious citizenship' (NUIG, 2014, 5).

The idea of mutually beneficial international partnerships is strong across university strategy documents and is evidence of the interface of all three configurations. It can be expressed through a liberal orientation such as in Western University's (Canada) International Action Plan: 'just as we share our knowledge across borders we must also learn from our international colleagues in true and mutually beneficial partnerships'. (WU, 2014a, 1). And SFU refers to its 'record of mutually beneficial local and global community involvement', and how it 'has always valued reciprocity in relationships with communities and community organizations'. (SFU, 2013, 18).

Similarly, UBC (2011) refers to benefits that 'flow both ways' (2) so that 'truly sustainable partnerships bring value for both parties' (UBC, 2011, 6). However, there are inherently two different types of strategic partnerships. There are strategic partnerships with 'universities or organizations that are highly respected internationally, within their geographic area, or within select fields of interest', as described in the University of Calgary's (Canada) International Strategy (UCal, 2013, 7). And, there are partners where higher education and research are at a 'very different stage of development', and where 'partnerships can be made that result in mutual benefits but those benefits may be different for each party...we may partner with organizations with a capacity building objective in the development context' (UBC, 2011, 6-7).

We found the focus on mutually beneficial relationships to be reflective of the ambivalent interfaces between rationales for, and orientations of, internationalisation in HE. Well-intended international development partnerships often present a deficit idea of bringing capacity to developing regions. Further, the idea of mutually beneficial 
relationship is also strongly framed by a neoliberal orientation. For example, UBC mentions building partnerships in India 'with a view to mutual benefits, rather than selfinterest...[and] take into account Indian partners' capacity-building objectives as well as our [UBC's] own desire to partner. This approach is not only fair, it is the only way to create a sustainable foothold for UBC in India.' (UBC, 2011, 20). Both UBC and SFU see these partnerships as part of building the 'Canadian brand' which is 'still not well known in India' (SFU, 2013, 22) and have sights on becoming a 'leader among Canadian institutions' in India (UBC, 2011, 20). They seek to 'leverage' the local diasporic Indian business community in the greater Vancouver area to build a competitive advantage (UBC, 2011, 21). This could be considered a neoliberal-critical interface if the more marginalized segments of that community are brought into internationalisation. As the examples illustrate, recognizing the importance of bettering lives, the significance of local context, and even the position of economic privilege may not revise significantly the modernist ontology and epistemology underlying ideas of international development.

\section{Mapping 'Sustainability'}

A similar pattern can be observed when sustainability is used in this exercise. When interpreted through a neoliberal discursive configuration, sustainability serves institutional interests: fiscal continuity, organizational efficiency, and ecological branding. ESD initiatives are often tied to financial imperatives as is the case in the document from Exeter University (U. K.) which states that 'sustainability principles will drive efficient and responsible management of campuses and operations, delivering measurable improvements in environmental performance... and best value is achieved in terms of financial, physical and natural resources' (UE, 2014, 5). The focus is on 
'enhancing the Exeter experience' $(2014,25)$ for the students who are consumers of the university's offerings. Sustainability is a key plank of marketing to prospective students. This marketability discourse also is evident in a liberal-neoliberal interface where, fore example, sustainability is a focus for problem solving and also for legitimizing the role of the university. Massey University (2014) states that 'advanc[ing]...understanding of and engagement with sustainability' is part of the university's role as 'voice and conscience of society' (MU, 2014, 22). At the same time, the Annual Plan frames this work on sustainability as a key market target outcome in its intent to "establish credible institutional brand and international reputation around sustainability leadership' (MU, 2013a, 25).

From a liberal discursive orientation, sustainability can be interpreted as initiatives to enable individuals to change their behaviours and attitudes thereby improving the environment. In the document from Södertörn University (Sweden), one paragraph evokes liberal and neoliberal configurations side by side. Diversity and intercultural skills connect naturally to sustainable development; these skills are poised as neutrally and positively producing the benefits of internationalism through knowledge mobilization which is an inevitable product of collaboration:

The university shall be an international higher education institution, where education and research are distinguished by diversity, widened perspectives and an intercultural approach. In addition, ordinary activities at the university shall offer... an international environment in which meetings between different cultures naturally occur. To increase international contacts, the university shall facilitate the development of new international networks and partners....Södertörn University shall also contribute to an internationalisation process that not only promotes its own activities, but which also includes environmental awareness and sustainable development. (1)

From a critical discursive orientation, where the focus shifts from individuals to 
systemic change, individual choices alone cannot change the structural issues at the root of environmental problems. This recognition is reflected in a suggestion by Webster (2004) to replace the slogan 'reduce, reuse, recycle' with 'rethink, refuse, reduce'. The latter, which is often used alongside the former, may add a cognitive element to the move from a focus on reducing one's carbon footprint to increasing one's handprint, that is, one's active involvement in addressing climate change (Hayward, 2013). One policy statement may not be able to reflect this nuance; however, it is important to demonstrate how easily the interfaces appear neutrally connected.

When mapped onto our social cartography, increasing one's handprint is tied back to a marketing and financial rationale if it does not challenge significantly systemic factors including political and social factors that reproduce the inequities and inequalities that are complicit in environmental issues. For example, Western University’s (Canada) strategic plan prioritizes 'working to increase environmental awareness and reducing our impact on the environment' $(2014 b, 12)$ : 'We will leverage our intellectual capacity to solve pressing environmental problems, while minimizing the impact of our campus community on the environment and educating students to be leaders in the environment and sustainability movement' (WU, 2014b, 20). This example connects to the finding by Van Poeck, Goeminne and Vandenabelle (this issue) of an emphasis in the ESD work they studied on reducing environmental impacts via behavioural precepts. They point out that a lack of attention to the multiplicity of attachments to a given sustainability issue can foreclose critical potential and merely enable superficial engagement. It is possible that pedagogy and programmatic initiatives open up that critical potential, but there is no evident directive in this regard in the document, and this is an area for future research. 
Ultimately, despite including an idea of 'rethinking', there is no 'refusing' in this example; rather, this is a strong example of the neoliberal-liberal interface where more intellectual capital will result in progress through individual actions and leveraging capacity. Similarly, n De Montfort University's (U. K.) strategic plan (2011) there is a neoliberal-liberal interface evident. While 'teaching about sustainability' helps students and staff become responsible 'global citizens in the face of the environmental challenges ahead of them' (DMU, 2011, 30, see also UR, 2009, 4), there is also a strong market rationale: 'Introducing sustainability to curricula, and providing students with opportunities to lead and contribute to our carbon management agenda, will be a distinct 'offer' in the higher education sector.' (DMU, 2011, 26). These are seen as mutually reinforcing rationales.

The university documents include very few examples of the critical discursive configuration. It is hinted at when interfaced with a stronger liberal configuration in notions of global citizenship and the social responsibility of the university. Using the social cartography to map the discourses can enable an iterative analysis whereby even when something is not found in the documents, by mapping out what is found, one can articulate what could be there. For example, a critical discursive configuration in internationalisation strategy documents could include a more rigorous analysis of the mechanisms and impact of global capitalism. Thus, the critical orientation to sustainability could question some of these attachments and assert a more critical version of the civic role of HEIs when a liberal orientation is easily re-framed by a corporate rationale. This could, for example, draw on work in indigenous approaches to global citizenship and global change (e.g., Andreotti et al., 2012; Ahenakew, Andreotti, Cooper, and Hireme, 2014). Yet, in being so closely tied to the liberal configuration which in turn is strongly framed by neoliberal rationales, we found that in the current 
HE strategy documents relating to internationalisation that we studied, the critical orientation is similar to the other two orientations in its imaginary and resulting reliance on and reassertion of a modern subject and a modern nation state.

Further, even if we found more critical approaches, the extent to which they would interface with liberal and neoliberal discourses raises the question of just how 'genuinely transformative' such approaches are (Huckle and Wals, 2015). All three orientations propose (different) solutions that rely on the same grammar and desires of modernity. They are attached to modern teleologies whereby sustainability is part of a seamless notion of progress in linear time. They are also attached to anthropocentric Cartesian conceptualization of agency reflected in the focus on changes in individuals' thinking and actions (see Kopnina and Cherniak [this issue] for further analysis of anthropocentrism in ESD). Both the liberal and critical orientations rely on the idea of the modern nation state as inherently benevolent and focused on the needs of citizens while an articulation of the neoliberal orientation exposes a privileging of the needs of property owners, tax payers, and consumers. Furthermore, all three discursive orientations are attached to totalizing forms of knowledge production where more and more rigorous research—based on the same systems of knowledge out of which global problems emerged will—solve those very problems. Consequently, as the discourses interface with one another, there is a constant production of more of the same sort of knowledge in a quest to find a singular solution which illustrates the circularity we mentioned before. 


\section{Conclusion: Ethical internationalism as intelligibility, dissent, and solidarity}

While international organizations call for a more transformative role of HEIs towards sustainability, and universities around the world take up a trend towards a vague but strong imperative to internationalise, ethical issues are often stepped over.

Similarly to and in conjunction with the paradigm of sustainable development (Banerjee, 2003), the internationalisation paradigm is largely based on an economic rationality that reorients and de-prioritizes the civic role of HEIs as spaces for critical debates about alternative futures (Nandy, 2000). As Orr (1994) pointed out, there is an underlying assumption that the answer to sustainability and development problems is education, and in interrogating this assumption, the inherent complexities as to what it means to educate for change and betterment in an era of international development and globalization emerge in important ways. What will these supposedly shared futures entail (McKenzie, 2012; Sund and Öhman, 2014)? What happens to conflict and complexity? Who belongs in these collective futures, and who is excluded?

By rooting our analysis in a decolonial critique of modernity, we contribute to the work in ESD (e.g. Bonnet, 2013; Jickling and Wals, 2012; Orr, 1999; Van Poeck, Goeminne, and Vandenabelle [this issue]) that seeks to make visible and interrogate taken-forgranted assumptions and to work through the inherent paradoxes of educating for sustainability in an era of neoliberalism and heightened individualism. Our analysis demonstrates that, in the case of internationalisation of HE, responding to neoliberalism with liberal and even some critical interjections may serve to reproduce the colonial systems of power embedded in the modern-colonial imaginary. While some critical orientations may selectively target oppressive patterns such as capitalist exploitation and processes of racialization, the many intersections with liberal and neoliberal 
discourses reproduce modern desires, including the desire to help and to be transformational, which are themselves implicated in the modern-colonial grammar that emphasizes self-affirmation and individual choice and agency.

We selected social cartography as a way to recognize that neoliberalism is the newest iteration of the contested but persistent modern-colonial imaginary and to map the main discursive orientations and their interfaces framing work in HEIs. This helped to iterate some of the foreclosures and conflations inherent to the multiple versions of internationalisation. Using the social cartography, we attempt to stimulate discussions and make specific paradoxes and conflations visible. Mapping key examples onto the three main discursive configurations and their interfaces provides an opportunity to identify both distinct and overlapping or ambivalent ways of engaging with internationalisation within a modern grammar. Without this type of contextualization and historicization of inherited ways of thinking at play in the current context, attempts towards transformative often ESD fail to significantly challenge the colonial grammar of modernity that defines relations of power in today's geopolitical realities. Examples from university strategy documents offer some illustrative examples of the discourses at work and in flux. The wider project will further examine localized nuances through student and faculty surveys and interviews with administrators and staff working directly with internationalisation in their universities.

We recognize that trying to move completely beyond the dominant global-imaginary that frames the discursive configurations identified in this cartography through any process or practice of higher education is extremely difficult (see also Andreotti, et al., 2015). The historical institutional conditions in which we work in HE are connected to the deep ways institutionalised education and academic research are complicit in and 
sustained through unjust, unfair and violent systems (Roy, 2006). In fact, trying to break with all elements of the modern-colonial grammar at once would likely be counterproductive. Even if we succeeded, the results would be un-intelligible to the institutions in which we seek to do the work and particularly to the funders enabling the work. Given the consensus regarding the important role of HEIs in promoting sustainable development and the parallel rush to internationalise HE, social cartographies such as the one we have offered here may encourage more breadth and depth in the conversations we have. We hope this may assist those of us involved with research on sustainable and international development in HE to continue work towards an ethical approach to internationalisation rooted in intelligibility, dissent, and solidarity.

\section{References}

Ahenakew, C., de Oliveira Andreotti, V., Cooper, G., and Hireme, H. 2014. "Beyond Epistemic Provincialism: De-provincializing Indigenous Resistance.” AlterNative, 10 (3): 216-231.

Andreotti, V. 2014. "Actionable Curriculum Theory: AAACS 2013 Closing Keynote." Journal of the American Association for the Advancement of Curriculum Studies, 10: 1-10. Retrieved from http://www.uwstout.edu/soe/jaaacs/upload/v10-Andreotti.pdf.

Andreotti, V. 2013. "Renegotiating epistemic privilege and enchantments with modernity: the gain in the loss of the entitlement to control and define everything." Social Policy, Education and Curriculum Research Unit, b-s. Retrieved from http://www.umassd.edu/seppce/centers/cfpa/.

Andreotti, V., Ahenkaew, C., and Cooper, G. 2012. "Equivocal Knowing and Elusive Realities: Imagining Global Citizenship Otherwise.” In Postcolonial Perspectives on Global Citizenship Education, edited by Vanessa Andreotti and Lynn Mario de Souza. 221-238, New York, NY: Routledge.

Andreotti, V., Jeferess, D., Pashby, K., Rowe, C., Tarc, P., and Taylor, L. 2010. "Difference and Conflict in Global Citizenship in Higher Education in Canada." 
International Journal of Development Education and Global Learning, 2 (3): 524.

Andreotti, V., Pashby, K., and Nicolson, M. 2014. "Ethics, Resistance and Dissent: An International Comparative Study of Internationalisation Policies in Higher Education in Times of Global Crises.” Paper presented at the Canadian Society for Studies in Education Conference, St. Catharines, ON. May 29.

Andreotti, V. and Souza, M. 2012. "(Towards) global citizenship education 'otherwise'." In Postcolonial Perspectives on Global Citizenship Education, edited by Vanessa Andreotti and Lynn Mario de Souza. 1-6, New York, NY: Routledge

Andreotti, V., Stein, S., Ahenakew, C., and Hunt, D. 2015. "Mapping Interpretations of Decolonization in the Context of Higher Education." Decolonization: Indigeneity, Education and Society, 4 (1): 21-40.

Andreotti, V., Stein, S., Pashby, K, and Nicolson, M. 2016. "Social Cartographies as Performative Devices in Research on Higher Education.” Higher Education Research \& Development, 1-16. DOI: 10.1080/07294360.2015.1125857

Baaz, M. E. 2005. The Paternalism of Partnership: A Postcolonial Reading of Identity in Development Aid. London: Zed Books

Banerjee, S. B. 2003. "Who Sustains Whose Development? Sustainable Development and the Reinvention of Nature." Organization Studies, 24 (1): 143-80.

Barnett, R. 2013. Imagining the University. New York, NY: Routledge.

Bessant, S. E. F., Robinson, Z. P., and Ormerod, M. 2015. "Neoliberalism, New Public Management and the Sustainable Development Agenda of Higher Education: History, Contradictions and Synergies.” Environmental Education Research, 21 (3): 417-432, DOI: 10.1080/13504622.2014.993933

Bonnet, M. 2013. "Sustainable Development, Environmental Education, and the Significance of Being in Place.” The Curriculum Journal 24 (2): 250-271.

Bourn, D. 2011. "From Internationalisation to Global Perspectives." Higher Education Research \& Development, 30 (5): 559-571, DOI: 10.1080/07294360.2011.598447.

Buchan, G. D., Spellerberg, I. F., and Blum, W. E. H. 2007."Education for Sustainability." International Journal of Sustainability in Higher Education, 8 (1): 4-15, DOI: 10.1108/14676370710717553. 
Calder, W., and Dautremont-Smith, J. 2009. "Higher Education: More and More Laboratories for Inventing a Sustainable Future.” Agenda for a sustainable America, 93-107. Available online:

http://usumfglobal.org/resources/0000/0070/ESDHigherEdAmericaCalder2009. pdf

Camicia, S. P., \& Franklin, B. M. 2011. "What type of global community and citizenship? Tangled discourses of neoliberalism and critical democracy in curriculum and its reform." Globalisation, Societies and Education, 9 (3-4): $311-322$.

Copernicus-Campus. 2006. COPERNICUS-Guidelines for Sustainable Development in the European Higher Education Area. Retrieved from http://www.unece.org/fileadmin/DAM/env/esd/information/COPERNICUS\%20 Guidelines.pdf.

De Montfort University (DMU). 2011. Strategic Plan 2011-2015. Retrieved from: http://www.dmu.ac.uk/documents/about-dmu-documents/executive-board/dmustrategic-plan.pdf.

Ferreira da Silva, D. 2007. Toward a Global Idea of Race. Minneapolis, MN: University Of Minnesota Press.

Ferreira da Silva, D. 2009. "Outline of a Global Political Subject: Reading Evo Morales's Election as a (Post-) Colonial Event." Seattle Journal for Social Justice 8 (1), 25-49.

Ferreira da Silva, D. 2013. "To be Announced: Radical Praxis or Knowing (at) the Limits of Justice." Social Text, 31 (1 114), 43-62.

Foucault, M. 1971. The Archaeology of Knowledge: Translated from the French by AM Sheridan Smith. New York: Pantheon Books.

Glover, A., Peters, C., and Haslett, S. K. 2011. "Education for Sustainable Development and Global Citizenship: An Evaluation of the Validity of the STAUNCH Auditing Tool." International Journal of Sustainability in Higher Education, 12 (2): $125-144$.

Goldberg, D. T. 1993. "Modernity, Race, and Morality." Cultural Critique, 24: 193227.

Government of Canada. 2014. Canada's International Education Strategy: Harnessing our Knowledge Advantage to Drive Innovation and Prosperity. Accessed Feb. 
25, 2015. http://international.gc.ca/global-markets-marches mondiaux/education/index.aspx?lang=eng.

Hayward. B. 2013. “The 'Emergence' of Democracy in New Urban Environments.” In Relational Architectural Ecologies: Architecture, Nature and Subjectivity, edited by Peg Rawes, 233-248. London: Routledge.

Higher Education for Sustainable Development Conference (HESD). 2014, Nov. 9. Nagoya Declaration on Higher Education for Sustainable Development. Accessed Feb. 24, 2015. http://www.c-linkage.com/for/hesd/declaration.html

Heron, B. 2007. Desire for Development: Whiteness, Gender and the Helping Imperative. Waterloo: Wilfrid Laurier University Press.

Huckle, J., and Wals, A. 2015. "The UN Decade of Education for Sustainable Development: Business as Usual in the End." Environmental Education Research, (21) 3: 491-505, DOI: 10.1080/13504622.2015.1011084

Hursh, D; Henderson, J., and Greenwood, D. 2015. "Environmental Education in a Neoliberal Climate." Environmental Education Research, 21 (3): 299-318, DOI: 10.1080/13504622.2015.1018141

Jefferess, D. 2008. "Global citizenship and the Cultural Politics of Benevolence." Critical Literacy: Theories and Practices, 2 (1): 27-36.

Jickling, B., and Wals, A. E. 2012. "Debating Education for Sustainable Development 20 Years after Rio A Conversation between Bob Jickling and Arjen Wals." Journal of Education for Sustainable Development, 6 (1): 49-57.

Kaapor, I. 2008. The Postcolonial Politics of Development. New York: Routledge.

Kelly, P. 2000. "Internationalising the Curriculum: For Profit or Planet." In The University in Transformation: Global Perspectives on the Futures of the University, edited by Sohail Inayatullah and Jennifer Gidley, 161-174. Westport: Bergin and Harvey.

Kim, T. 2010. "Transnational Academic Mobility, Knowledge and Identity Capital." Discourse Studies in the Cultural Politics of Education, 31 (5): 577-591.

Khoo, S. 2012. "Rerouting the Postcolonial University: Educating for Citizenship in Managed Times." In Postcolonial Perspectives on Global Citizenship Education, edited by Vanessa Andreotti and Lynn Mario de Souza, 200-220. New York, NY: Routledge. 
Lather, P. 2006. "Paradigm Proliferation as a Good Thing to Think With: Teaching Research in Education as a Wild Profusion.” International Journal of Qualitative Studies in Education, 19 (1), 35-57.

Massey University (MU). 2013. Annual Plan 2013. Retrieved from http://www.massey.ac.nz/massey/fms/About\%20Massey/Documents/AnnualPlan-2013.pdf?3D71F8ACC863C79628F4F3CA9602BB4F

Massey University (MU). 2014. Shaping the Nation: Taking the Best to the World, The Road to 2025. Retrieved from http://www.massey.ac.nz/massey/fms/About\%20Massey/UniversityManagement/documents/156512\%20Road\%202025\%20WEB.pdf?E16946928C 096DBABD84BC20911E8BEC.

McEwan, C. 2009. Postcolonialism and Development. London and New York: Routledge.

McKenzie, M. 2012. 'Education for Y'all: Global Neoliberalism and the Case for a Politics of Scale in Sustainability Education Policy." Policy Futures in Education, (10) 2: 165-177. http://dx.doi.org/10.2304/pfie.2012.10.2.165 Mignolo, W. 2000a. Local Histories/Global Designs: Essays on the Coloniality of Power, Subaltern Knowledges and Border Thinking. Princeton: Princeton University Press.

Mignolo, W. 2000b. "The Many Faces of Cosmo-polis: Boarder Thinking and Critical Cosmopolitanism." Public Culture, 12 (3): 172-748.

Mignolo, W. 2002. “The Geopolitics of Knowledge and the Colonial Difference.” The South Atlantic Quarterly 101 (1): 57-94.

Mignolo, W. 2011. The Darker Side of Western Modernity: Global Futures, Decolonial Options. Durham, NC: Duke University Press.

Mooers, C. 2014. Imperial Subjects: Citizenship in an Age of Crisis and Empire. London: Bloomsbury Publishing.

Mochizuki, Y., and Bryan, A. 2015. "Climate Change Education in the Context of Education for Sustainable Development: Rationale and Principles”. Journal of Education for Sustainable Development, 9 (1): 4-26.

National University of Ireland Galway (NUIG), International Sub-Group. 2014. June 13. International Sub-Group, Strategic Plan 2015-2020. Internationalisation 
Orr, D. W. 1994. Earth in mind: On education, environment, and the human prospect. Washington, D. C.: Island Press.

Pashby, K., and Andreotti, V. 2015. "Towards Justice and Ethics in Internationalisation in Higher Education: An International Comparative Mapping of National Strategies." Paper presented at the American Education Research Association, Chicago, IL, April 19.

Pashby, K., and Shultz. L. 2016. "Global citizenship and ethical internationalisation in higher education: Student perspectives from Canada and Kenya.” Paper presented at the Comparative International Education Society, Vancouver, B. C., March 7.

Paulston, R. 1999. "Mapping Comparative Education after Postmodernity." Comparative Education Review, 43 (4): 438-463.

Paulston, R. 2000. “A Spatial Turn in Comparative Education? Constructing a Social Cartography of Difference." In Discourse Formation in Comparative Education, edited by Jürgen,Schriewer, 297-354. New York: Peter Lang.

Paulston, R., and Liebman, M. 1994. "An invitation to postmodern social cartography." Comparative Education Review, 38 (2): 215-232.

Roy, A. 2006. "Praxis in the Time of Empire." Planning Theory 5 (1): 7-29.

Rust, V. D., and Kenderes, A. 2011. "Paulston and Paradigms." In Beyond the Comparative: Advancing Theory and its Application to Practice, edited by John C. Weidman, W. James Jacob, 19-29. Boston, MA: Sense Publishers.

Sammalisto, K., and Lindhqvist, T. 2008. "Integration of Sustainability in Higher Education: a Study with International Perspectives." Innovative Higher Education, 32 (4): 221-233.

Simon Fraser University (SFU). 2013. International Engagement Strategy: SFU International External Relations 2013-2016. Retrieved from http://www.sfu.ca/content/dam/sfu/international/documents/Int\%20Engagement \%20Strategy.pdf.

Slaugher, S., and Rhoades, G. 2004. Academic Capitalism and the New Economy: Markets, State, and Higher Education. Baltimore: The Johns Hopkins University Press.

Södertörn University (SU). 2012, Nov. 15. Internationalisation Policy. Governing Board Reg. no. 1910/40/2012. 
Sousa Santos, B. 2007. "Beyond Abyssal Thinking: From Global Lines to Ecologies of Knowledge." Review (Fernand Braudel Center), 30 (1), 45-89.

Spivak, G. 1999. A Critique of Postcolonial Reason: Toward a Critique of the Vanishing Present. Cambridge, MA: Harvard University Press.

Spivak, G. 2002. "Righting Wrongs" - unpublished paper.

Stein, S. and, Andreotti, V. forthcoming. "Higher education and the modern/colonial global imaginary." Cultural Studies <-> Critical Methodologies.

Stein, S., and Andreotti, V. 2015. "Cash, competition, or charity: International students and the global imaginary." Higher Education. http://dx.doi.org/10.1007/s10734-015-9949-8

Sund, L., and Öhman, J. 2014. "On the Need to Repoliticise Environmental and Sustainability Education: Rethinking the Postpolitical Consensus." Environmental Education Research, 20 (5): 639-659, DOI: $10.1080 / 13504622.2013 .833585$

Thomas, I. 2004. "Sustainability in Tertiary Curricula: What is Stopping it Happening?" International Journal of Sustainability in Higher Education, 5 (1): 33-47. Retrieved from http://www.emeraldinsight.com/doi/pdfplus/10.1108/14676370410517387

University Leaders for a Sustainable Future (ULSF). 1990. The Talloires Declaration. Retrieved from http://www.ulsf.org/programs_talloires_td.html

University of Alberta (UA). 2010. International Resource Document for the Academic Plan 2011-2015. Retrieved from http://www.international.ualberta.ca/en/AboutUniversityofAlbertaInternational/ 〜/media/uai/docs/UAlberta_International_Resource_Document_Nov_2010.pdf

University of British Columbia (UBC). 2011. International Strategic Plan. Retrieved from http://research.ubc.ca/sites/research.ubc.ca/files/uploads/documents/VPRI/UBCintl-stratplan-2011.pdf

University of British Columbia (UBC). 2012. Place and Promise: the UBC Plan. Retrieved from http://strategicplan.ubc.ca/files/2009/11/UBC-PP-LayoutAug2012.pdf. 
University of Calgary (UCal). 2013. Becoming a Global Intellectual Hub: Highlights of the University of Calgary International Strategy. Retrieved from http://ucalgary.ca/research/files/research/becoming-a-global-intellectualhub.pdf.

University of Exeter (UE). 2014. 2015: Our Vision, Our Strategy. Retrieved from: http://www.exeter.ac.uk/media/universityofexeter/webteam/shared/contentimage s/strategicplan/Strategic_Plan_2015.pdf.

University of Helsinki. (UH). 2012. The Best for the World: Strategic Plan for the University of Helsinki 2013-2016. Retrieved from: http://www.helsinki.fi/strategia/pdf/strategia_2013-2016_eng.pdf.

University of Regina (UR). 2009. Mâmawohkamâtowin: Our Work, Our People, Our Communities, Strategic plan 2009-2014. Retrieved from http://www.uregina.ca/strategic-plan/assets/docs/pdf/sp-2009-14.pdf.

Webster, K. 2004. Rethink. Refuse. Reduce...Education for sustainability in a changing world. Shrewsbury, UK: Field Studies Council Publications.

Weidman, J. C., and Jacob, W. J. 2011. "Mapping Comparative, International, and Development education". In Beyond the Comparative (pp. 1-16). Sense Publishers.

Western University (WU). 2014a. International Action Plan 2014-2019. Retrieved from http://international.uwo.ca/pdf/International\%20Strategy\%202014-2019.pdf.

Western University. (WU). 2014b. Achieving excellence on the world stage. Retrieved from http://president.uwo.ca/pdf/strategicplan/WesternU_Full_StratPlan_2014.pdf.

${ }^{\mathrm{i}}$ The conference was co-organized by UN University; Ministries of the Environment, of Education, of Culture, Sports, Science and Technology-Japan; and Nagoya University in collaboration with various UN organizations including UNESCO, the UN Department of Economic and Social Affairs (UN DESA), UN Environment Programme, UN Global Compact Principles for Responsible Management Education initiative and the International Association of Universities. See http://unu.edu/events/archive/conference/higher-education-for-sustainable-developmentbeyond-2014.html

\footnotetext{
${ }^{i i}$ For a complete list of signatories see http://www.ulsf.org/programs_talloires_signatories.html
} 
iii Funded by the Academy of Finland, and led by principal investigator Dr. Vanessa Andreotti, the project involves over 20 universities across 5 continents and involves a four-phased mixed-methods comparative analysis: analysis of strategic documents, surveys with 200 under graduate students (100 in education and 100 in another discipline), surveys with 20 faculty members (10 from education and 10 from the other discipline), and interviews with administrators directly involved in international activities.

${ }^{\text {iv }}$ Paulston and Liebman (1994) indicate, the idea of social cartography is similar to both cognitive mapping and geographic cartography.

${ }^{v}$ These included wider strategy documents and annual reports (Canada: University of British Columbia, University of Regina, and Western University; Finland: University of Helsinki; New Zealand: Massey University; U.K.: De Montfort University; University of Exeter) as well as specific documents pertaining to internationalisation (Canada: Simon Fraser University, University of Alberta, University of British Columbia, University of Calgary, Western University; Ireland: National University of Ireland at Galway; Sweden: Södertörn University). As there are more Canadian universities participating in the larger project than in other countries, there are also more Canadian university documents included in the examples provided in this paper. The intention of this analysis is not to consider a national comparison of discourses (which would be a very interesting study) but rather to examine discourses across these documents and contexts.

${ }^{\mathrm{vi}}$ It would be outside the scope of this paper to consider another layer of analysis; however, future research will consider discourses of internationalisation evident in documents from the universities in both the Global North and the Global South (Pashby and Shultz, 2016). 